\title{
THE LACASA AREA, RANGER DISTRICT, NORTH-CENTRAL TEXAS.
}

\author{
By Clarence S. Ross.
}

\section{INTRODUCTION.}

The area 6 miles square described in this report lies in the Ranger oil district, in the southeastern part of Stephens County, Tex., its south line corresponding approximately with the south border of the county and its east line lying 6 miles west of the east border of the county. (See fig. 50.) The village of Lacasa, after which it has been named, is near its northeast corner. Strawn, on the Texas \& Pacific

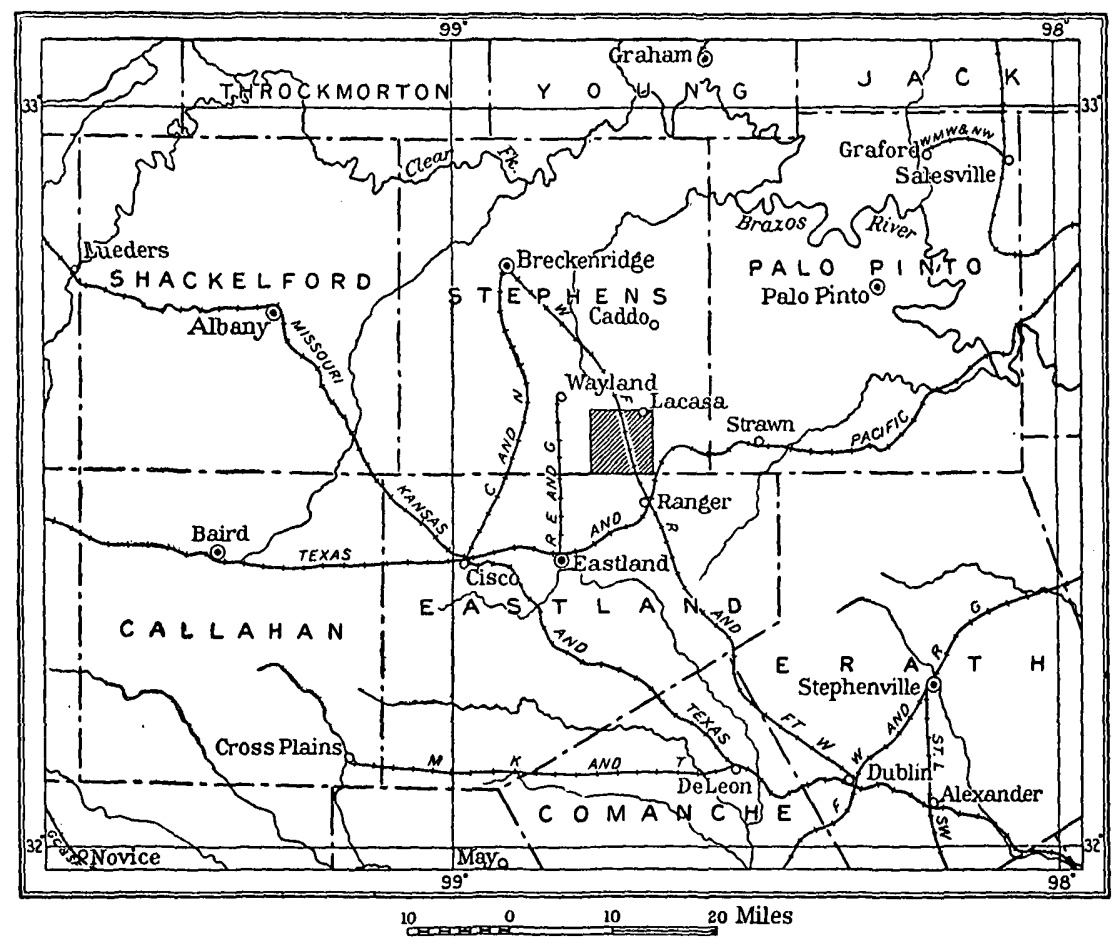

FrgURE 50.-Key map of north-central Texas showing location of Lacasa area.

Railroad, is about 10 miles east of its east border, and Ranger, on the same road, lies 4 miles south of the south border. Caddo Creek drains the eastern part of the area and flows in a general northeasterly direction, crossing the north line not far from the village of Lacasa. 
Gonzales Creek and its tributaries drain the western part of the area and flow in a northwesterly direction, leaving the area near its northwest corner. The country is gently rolling, and the maximum relief is about 320 feet. The eastern and northern parts are the most rugged, and the southern part is characterized by high sand flats. About one-third of the area is covered by timber, in which scrub oak predominates.

The field work was done during April and May, 1919, by the writer, assisted by W. G. Argabrite. Locations and elevations for working out the geologic structure were determined by plane table and telescopic alidade.

For convenience in reference the Lacasa area has been arbitrarily divided into 144 blocks by 12 north-south coordinates and 12 eastwest coordinates, as shown on Plate LIII. Beginning at the upper left-hand corner of the area the blocks are numbered consecutively toward the east and lettered consecutively toward the south. Thus K-5 designates a block 11 units south and 5 units east from the northwest corner of the area, or, as each block is half a mile square, $5 \frac{1}{2}$ miles south and $2 \frac{1}{2}$ miles east from the northwest corner.

\section{STRATIGRAPHY.}

\section{GENERAL CHARACTER OF EXPOSED ROCKS.}

The rocks exposed at the surface in the Lacasa area, having an aggregate thickness of about 600 feet, are illustrated graphically in figure 51. The oldest are Pennsylvanian; above these are Cretaceous rocks; and still younger beds are probably Tertiary. Local unconformities occur within the Pennsylvanian, and profound unconformities between the Pennsylvanian and Cretaceous and between the Cretaceous and the Tertiary(?).

Pennsylvanian rocks are exposed in the northern and eastern part of the area, those in the northern and northeastern parts belonging to the Cisco formation and those along the eastern border to the Canyon formation. The Canyon formation is characterized by massive limestones with intervening shales and sandstones. Shales predominate in the Cisco formation, but thin limestones are present and massive sandstones form considerable part of the formation.

After the deposition of the Pennsylvanian beds they were subjected to profound erosion, and after the lapse of a long period of geologic time the Trinity sand, of Lower Cretaceous age, was deposited unconformably upon them. The Trinity consists of conglomerates, sandstones, unconsolidated sands, siltlike material, clay, and some siliceous limestones, the whole very much cross-bedded. The pebbles of the conglomerate consist partly of such local material as limestone, sandstone, and shale, but most of them are foreign quartzite, vein quartz, or chert. Where the conglomerate has withstood 
the disintegrating action of weathering the spaces between the pebbles are filled with fine sand, which is firmly cemented with calcium carbonate. Over most of the area where the conglomerate is present, however, it has broken down into a mass of loose sand with pebbles and cobbles scattered through it, and the original nature and appearance of the indurated bed must be determined from small fragments that have withstood disintegration and from a few good exposures where the Cretaceous rocks are protected by a resistant layer of more recent material.

The conglomerate that caps the hills over much of the area and lies unconformably above the Cretaceous beds contains silicified wood, but no fossils have been found that permit a definite determination of its age.

It has been provisionally assigned to the Tertiary, but it is possibly of the same age as beds that have been called "Lafayette" in other parts of Texas. ${ }^{1}$ It is made up of quartzite, quartz, and chert sand grains and pebbles reaching maximum dimensions of several inches. The only fragments of local rocks that have been recognized are

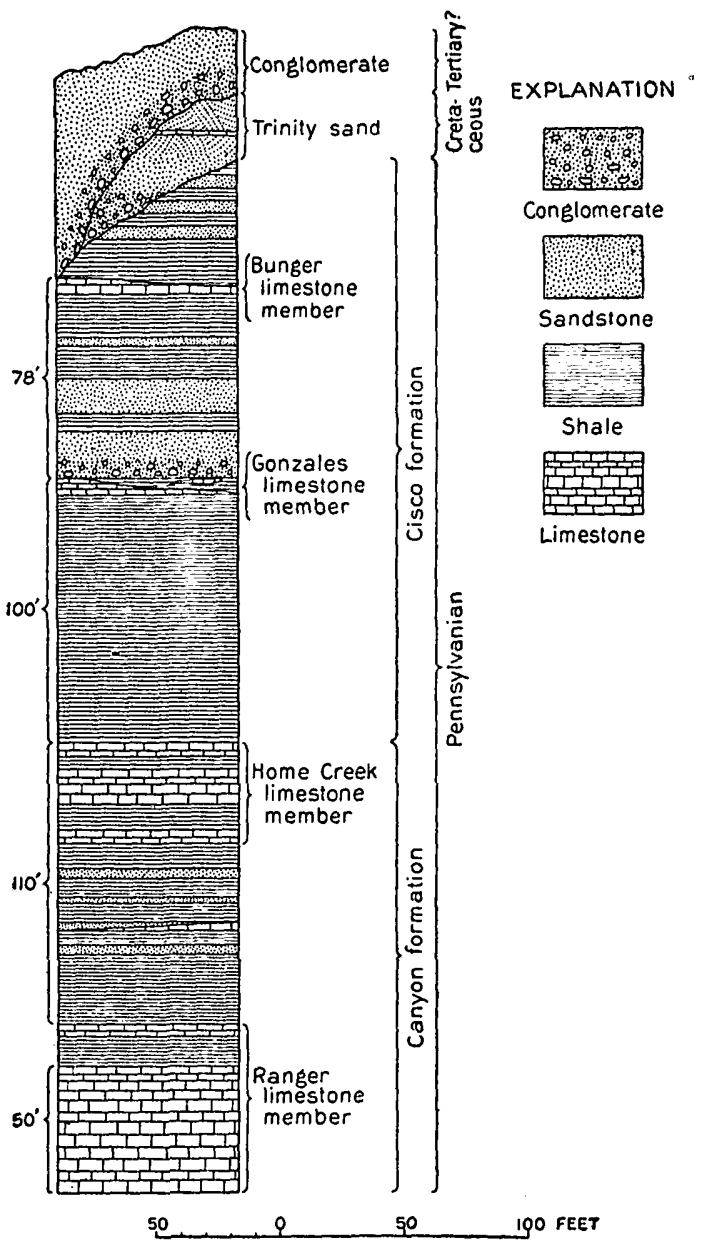

Figure 51.-Columnar section of rocks exposed in Lacasa area, Tex.

rounded boulders of Trinity conglomerate. These materials are similar to those of the Trinity and no doubt have been derived in part or wholly from that formation, thus making it diffcult to distinguish the two conglomerates. The Trinity has a cement of calcium carbonate, but the later conglomerate has a cement of chalcedony which gives it great resistance to weathering. The pebbles from the Trinity are waterworn but are not well rounded.

1 Udden, J. A., Baker, C. L., and Böse, Emil, Texas Univ. Bull. 44, p. 91, 1916. 
Those from the later conglomerate show a greater degree of attrition, and 90 per cent of the pebbles over an inch in diameter are dreikanters or show other evidences of wind erosion, thus presenting clear evidence that these beds were deposited under desert conditions.

\section{KEY BEDS.}

The beds that have been useful in mapping the geologic structure of the Lacasa area, named in the order of their deposition, are the main and upper benches of the Ranger limestone, the base and top of the Home Creek limestone, the Gonzales limestone, a fossil-bearing zone just above it, and the Bunger limestone. The sandstones have proved to be of little value in working out the geology, as they have very indefinite tops and can not be traced continuously.

Names.-So far as possible the names given to the beds have been those used by Frederick B. Plummer, geologist of the Roxana Petroleum Co. Mr. Plummer presented a preliminary paper ${ }^{1 a}$ on the stratigraphy of the Pennsylvanian formations of north-central Texas before the American Association of Petroleum Geologists at Dallas, Tex., in March, 1919, and has submitted a later unpublished paper to the United States Geological Survey for suggestions. In the later paper the names proposed by Drake ${ }^{2}$ for the Colorado coal field have been used wherever suitable and where definite correlations have been possible. The bed which Mr. Plummer called "Eastland limestone" in the preliminary paper has now been correlated with the Home Creek limestone of the Colorado coal field. North-central Texas is the type area for all the other beds described in the present paper, and local names have been used by Mr. Plummer. The name Gonzales limestone is here given by the writer to the limestone exposed in the bed of Gonzales Creek.

Ranger limestone.-In the southeastern part of the Lacasa area occurs the Ranger limestone, the lowest bed appearing at the surface in the area. The main bench of the Ranger is a light-gray massive limestone 50 feet thick, forming a distinct and easily traceable scarp. The topmost ledge is a thin-bedded buff limestone 4 feet thick lying 16 feet above the main bench, from which it is separated by 12 feet of shale.

Home Creek limestone.-The Ranger limestone is overlain by about 70 feet of shale containing several thin-bedded calcareous sandstones and lenticular limestones. The only prominent lens of limestone forms a ledge lying 39 feet above the top of the Ranger. In the northern part of the Lacasa area it is 3 feet thick, but it thins toward the south and is entirely absent at the southern border. A series of alternating limestones and shales extending from 70 to 110 feet above

la Plummer, F. B., Am. Assoc. Petroleum Geologists Bull., vol. 3, pp. 132-145, 1919.

2 Drake, N. F., Report on the Colorado coal fleld: Texas Geol. Survey Fourth Ann. Rept., pp. 257-446, 1893. 
the top of the Ranger limestone and locally known as the "Caddo lime" has been correlated with the Home Creek limestone by Plummer. Drake did not interpret the Home Creek as the top of his Canyon division in the Colorado coal region, but the top of the Home Creek appears to be the dividing line between the Cisco and the group of heary limestones to which Cummins ${ }^{3}$ gave the name Canyon in his report on the geology of the northern coal region, of which this area is a part. In the southeastern part of the Lacasa area the lowest limestone of the Home Creek member forms a continuous scarp about 76 feet above the top of the Ranger. Above this ledge are several benches of fine-grained light-gray limestone without fossil-bearing beds that can be used as horizon markers. No good section of the upper part of the Home Creek can be measured in this region, but by comparison of the structure contours the top is found to be about 110 feet above the top of the Ranger.

Gonzales limestone.-Above the Home Creek limestone lies a series of shales about 96 feet thick, which in the Lacasa area have been cut away by Caddo Creek to form a large valley. The east side of this valley is the alluvium-covered dip slope of the Home Creek limestone. The west side is a scarp capped by a limestone, which is also exposed along the headwaters of Gonzales Creek, and from these exposures it is herein named the Gonzales limestone member of the Cisco formation.

The Gonzales limestone occupies a position in the geologic section corresponding closely with that of a bed occurring in the vicinity of Jacksboro, to which Plummer has given the name Jacksboro limestone, and both beds are characterized by unusual numbers of Campophyllum. Plummer states that the Jacksboro thins towaid the south and disappears 10 to 15 miles southwest of Jacksboro, and the writer finds that the Gonzales thins toward the north and disappears near the north border of the Lacasa area, leaving an interval of nearly 40 miles over which neither bed has been traced. For this reason a local name has been used for the limestone found in the Lacasa area.

Although the Gonzales limestone is thin or entirely missing in the northern part of the area it thickens rapidly toward the south and reaches a maximum thickness of about 4 feet. It is a coarse-grained dark-gray limestone containing large numbers of Campophyllum, and locally a thin shaly limestone carrying many specimens of Myalina subquadrata lies 8 feet above it. The interval between the top of the Home Creek limestone and the top of the Gonzales limestone can not be measured directly in this region but is about 100 feet. The top of the Gonzales is marked by a slight unconformity. In most of the area it is overlain by only a few inches of shale, above

${ }^{8}$ Cummins, W. F., Geology of northwest Texas: Texas Geol. Survey Second Ann. Rept., p. 374, 1890. 
which lies a very massive bed, the base of which is an intraformational conglomerate containing ferruginous clay pebbles. This grades into a conglomerate composed of light-colored chert pebbles with quartz sand filling the interstices, and this conglomerate in turn grades into a normal sandstone whose top is about 20 feet above the top of the limestone. A second bench of sandstone slightly less massive than the first lies about 22 feet higher still. All the sandstones thicken from the northern to the southern part of the region. Shales predominate in the succeeding 31 feet, but a thin-bedded calcareous sandstone 16 feet above the second bench of sandstone and richly fossiliferous limestone lenses are common in the northern part of the area. Thin coal bands are locally present near the base of the shale.

Bunger limestone.-About 78 feet above the top of the Gonzales limestone lies a very persistent limestone which has. been called by Plummer the Bunger limestone. It is light gray, contains but few fossils, and forms a bench 2 to 5 feet thick. It makes a low but easily traced escarpment facing toward the southeast in the north-central part of the area and occurs along both sides of Gonzales Creek and its tributaries in the northwestern part. Above it is a series of alternating shales and sandstones containing chert conglomerates, and the highest bed in the Lacasa area is a sandstone lying about 60 feet above the Bunger.

\section{STRUC'TURAL FEATURES.}

\section{GENERAI STRUCTURE.}

The geologic structure described below and portrayed on the contour map (Pl. LIII) is determined by observations on the beds of Pennsylvanian age. Although in some places the attitude of the overlying Cretaceous and Tertiary (?) rocks can be determined, it is believed that most of the deformation which affected the oil-bearing beds took place before Cretaceous time, and that observations on the Cretaceous and post-Cretaceous beds will not be of assistance in determining the location of deep-lying folds that may be of economic importance.

The general structure of the Lacasa area conforms to that of the Pennsylvanian beds of north-central Texas as a whole and shows a normal northwesterly dip averaging about 50 feet to the mile. The structure contours shown on Plate LIII are based for the most part upon observations on beds exposed at the surface; but in the south and central parts of the area rock outcrops are lacking, and well records have been used wherever available to determine the position of key beds. The structure contours are drawn on the surface of a theoretical bed lying approximately 260 feet below the top of the highest bed of the Ranger limestone. The position of the contours shown 


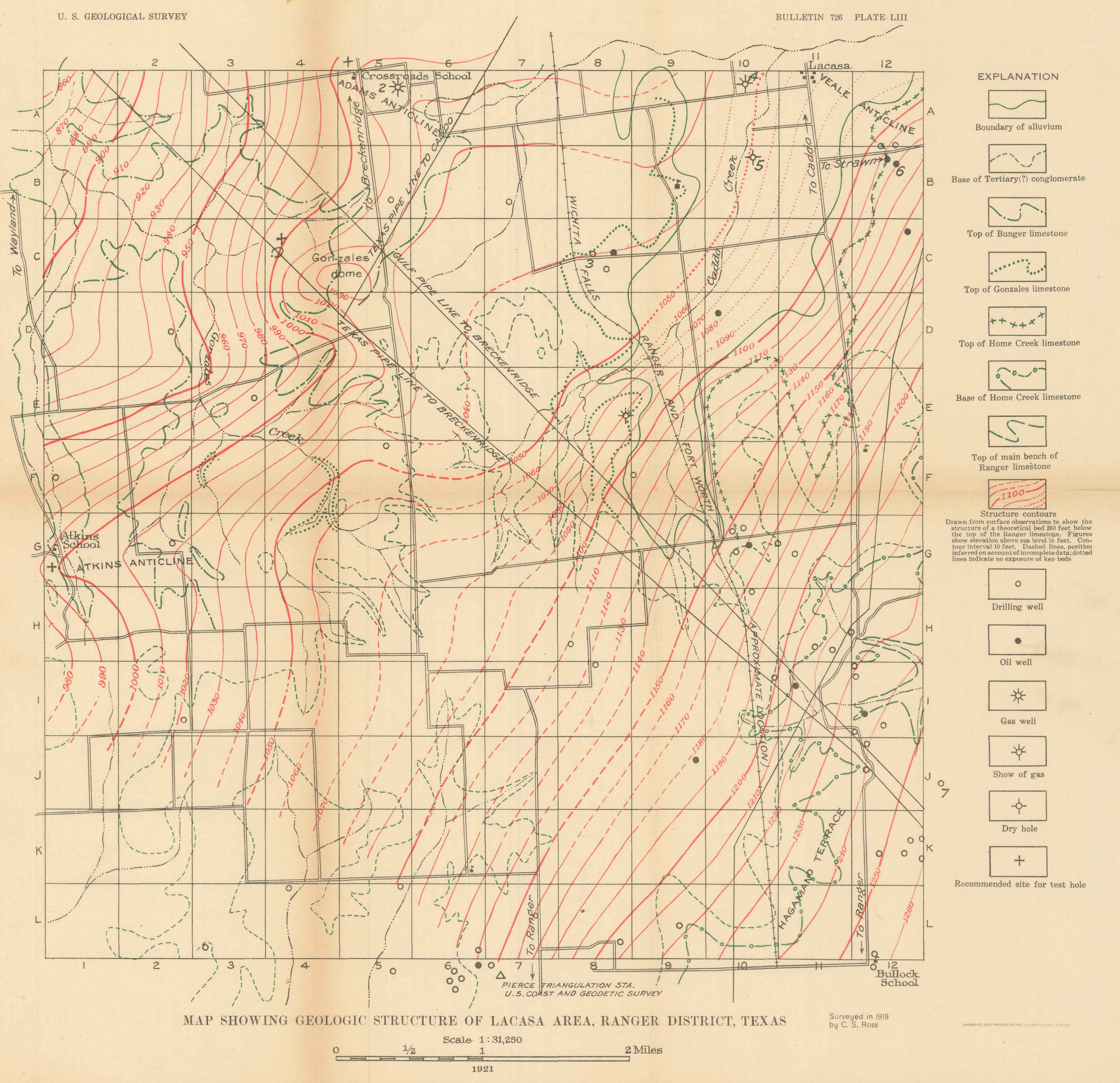


by broken lines is open to some doubt, owing to the lack of exposures of Pennsylvanian beds.

A study of the oil production in the Ranger field shows that the best yields of oil are obtained in areas where the surface beds show terraces, noses, or dipping anticlines. These surface features commonly mark much more sharply accentuated folds in the oil-yielding beds, and a surface fold that shows no closure may overlie a subsurface fold with a large closure.

\section{AREAS OF FAVORABIE STRUCTURE.}

In the Lacasa area there is a large pitching terrace in the southeastern part, a pitching anticline in the northwestern part, and a group of three noses or pitching anticlines in the central and northern parts. These features are described below.

\section{HAGAMAN TERRACE.}

In the Hagaman terrace, in the extreme southeast corner of the Lacasa area, the rocks dip to the northwest at only about half their normal rate. It extends eastward into the Wiles area and southward into the East Ranger area, and in the Lacasa area it covers all the territory south and east of a line running between squares G-12 and L-9. (See P1. LIII.) It is marked by a pronounced moderation of the regional dip east of the line mentioned, with correspondingly steep dips west of the line. East of the "step" of the terrace, in the Wiles and East Ranger areas, the beds rise sharply southeastward. Such folding as has taken place has been parallel to the strike of the beds, and there is nothing in the Lacasa area to indicate cross folding in any other direction.

The terrace had been fairly well outlined by producing wells at the time the field work was done (May, 1918), and a great many test holes were being drilled. To judge from conditions known to prevail elsewhere in the Ranger district, the folding in the oil sands is.more pronounced than that at the surface, and oil will probably be obtained outside the limits that would be set were surface structure alone considered. The work of comparing subsurface and surface folding has not yet been carried far enough to justify positive statements regarding the probable extent of producing area, but it appears probable that oil will be found farther to the west of the area of low dip than to the east of it, as in this particular part of the Ranger district preliminary work indicates that the deep-lying folds are likely to be offset to the west with respect to surface folds.

VEALE ANTICLINE.

In the northeastern part of the Lacasa area alluvium along Caddo Creek prevents complete mapping of the surface beds, but those that 
are traceable indicate a small pitching anticline beginning about a mile southeast of Lacasa and extending in a northwesterly direction into the Necessity area, to the north. This fold is here called the Veale anticline. Oil is being produced in commercial amounts from the Veale sand at a depth of about 3,800 feet in several wells in this area, and the reported initial daily production ranges from 80 to about 700 barrels. The probable extension of the field can not be foretold until the areas to the north and northeast have been mapped, but new wells can be expected north and west of those now developed. The Veale sand is within the Marble Falls limestone.

\section{ADAMS ANTICLINE.}

The Adams antıcline, which runs in a northwesterly direction across blocks B-6, B-7, A-5, and A-6 (see Pl. LIII) into the Necessity area, to the north, forms one of the most promising undeveloped oil localities in the region. On the east the anticline is bordered by a shallow pitching syncline in blocks $\mathrm{B}-9, \mathrm{~A}-8$, and A-9. On the southeast it merges into a large flat. On the south a shallow pitching syncline separates it from the Gonzales dome. The continuation of this anticline into the Necessity area has not yet been mapped (July, 1919).

The Adams gas well, in block A-5, on the crest of the anticline, reaches a gas sand at a depth of 2138 feet, but the deeper sands have not been tested in this locality. Wells drilled east and west of the Adams well along the north border of the area allow a study of the subsurface beds in this anticline. The Maxwell well No. 1 of the Texas \& Pacific Co., 1 mile west of block B-1, was dry at a depth of 3,833 feet. The distance between this well and the Adams well is $3 \frac{1}{2}$ miles, and both the surface beds and the subsurface beds show a westerly dip between these points. Along the axis of the anticline, 13 miles southeast of the Adams well, is the Haney well, which was practically dry at a depth of 3,527 feet. Between these two points the surface beds show a slight northwesterly dip, and the subsurface beds dip in the same direction at about the same rate.

The Bradford well, in block A-10, $1 \frac{1}{2}$ miles northeast of the Haney well, had not quite reached the producing sands at a depth of 3,490 feet when the field examination was completed. This well and the Haney well are approximately on the strike of the surface beds, but the subsurface beds show a northeasterly dip that gradually increases with increasing depth. The top of the Smithwick shale, at a depth of about 3,050 feet, shows a reversal of dip of about 80 feet in $1 \frac{1}{2}$ miles. The Bobo well, about half a mile south of the Bradford well, in block B-10, is dry at a depth of 4,140 feet. It is slightly up the dip of the surface beds from the Bradford well, but at the top of the Smithwick shale there is a southerly dip of 90 feet in half a mile. The Veale well 
is 1 mile east of the Bobo well, and between these two points both the surface beds and the subsurface beds dip normally to the west.

These data indicate that the subsurface structure of the Adams anticline is marked by an eastern flank dipping sharply to the east, beyond which there is a sharp syncline occupying approximately the position of the syncline trending northwest from the Bobo well that has been mapped on the surface beds. Favorable locations for test wells lie along the crest of the anticline north and west of the Adams gas well.

GONZALES DOME.

Just east of Gonzales Creek in blocks C-4, C-5, D-4, and D-5 (see Pl. LIII) lies a low anticline with about 15 feet of closure that has been called the Gonzales dome. It is separated from the 1 dams anticline by a shallow westward-pitching syncline. On u south is a sharp westward-pitching syncline, and on the east lies a southern continuation of the flat that lies east of the Adams anticline.

The axis of this fold trends almost due west, diverging a few degrees from parallelism with that of the Adams anticline. The flexure is not nearly as extensive in an east-west direction as the Adams anticline, to the north, and the Atkins anticline, to the south, but some indication of it can nevertheless be detected $1 \frac{1}{2}$ miles west of the center of the dome.

No test holes have been drilled either on or near the axis of this fold, so its possibilities for oil production are not known. Furthermore, such test holes as were being drilled near by while the field work was in progress were not located advantageously with respect to the surface structure, and their failure would not condemn land nearer the axis of the flexure, although their success would make the territory that seems structurally more favorable appear particularly promising. Probably the most favorable location for a test well lies in the northwest corner of block C-4.

The outline of the Gonzales dome as shown on the structure map was controlled largely by elevations on the Bunger limestone, which furnished a reliable datum.

\section{ATKINS ANTICLINE.}

A pitching anticline extends from blocks $\mathrm{F}-5$ and $\mathrm{G}-5$ westward toward the Atkins School, in block G-1, after which it has been named, and crosses into the Gunsight area, to the west, just beyond that school. The plunging axis trends approximately parallel to those of the Adams anticline and the Gonzales dome. The dips to the northwest and southwest are pronounced, but to the east the anticline merges gradually into the regional monocline.

At the time the examination was made no wells had reached the beds which elsewhere in this region have proved to be oil bearing, $26801^{\circ}-22-$ Bull. $726-21$ 
and there is no hint as to the relation which the deep-seated structure may bear to that exhibited at the surface. However, a test drilling in block G-2, almost on the axis of the fold, and one in block F-1, on its northwest flank, should furnish a reliable indication of what may be expected in the way of production. The location of the well being drilled in block F-5 does not appear to be quite as favorable as the two mentioned above, but to judge purely from the surface indications this well should yield oil or gas. A comparison of the records of this well and those farther west will reveal the presence or absence of an easterly dip in the deep-lying beds. Should such a dip be present, the probability that there is a large anticline in the Smithwick and Marble Falls formations, underlying the strip covered by the Atkins, Gonzales, and Adams anticlines, should be considered. If this proves to be the case the synclinal areas that separate the surface folds can not be considered unfarorable for oil accumulation.

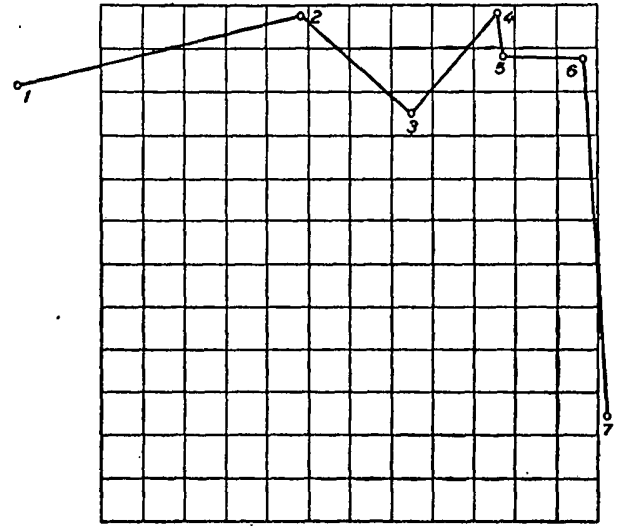

FrgURE 52.-Key map of Lacasa area, Tex., showing location of wells whose logs are given in Plate LIV.

The outline of the Atkins anticline was determined by elevations taken on outcrops of the Gonzales and Bunger limestones, which furnished reliable data upon which to base the structure.

\section{AREAS OF UNFAVORABIE STRUCTURE.}

Monoclines are not usually considered favorable localities for the accumulation of oil. In north-central Texas, however, the subsurface structure does not exactly correspond to that shown by the surface beds, and the conditions of the sand are known to have an important bearing on the accumulation of oil, and for these reasons the monoclinal areas that cover much of the Lacasa area can not be condemned as barren of oil.

The areas where marked synclines occur must be considered probably unfavorable for oil. The Bobo well, which was drilled in one such syncline, failed to yield either oil or gas, and the axis of this downwarp should be avoided in drilling. The syncline extending westward from the southeast flank of the Gonzales dome is also iunfavorable. The sympline lying south of the Atkins School is not as sharp as the one last meptioned, but it is not nearly so favorable as the Atkins anticline, farther north. 
WELLS.

The following table shows the names of some of the wells drilled or being drilled in the Lacasa area when it was examined, in May, 1919, the location of each well as indicated by the coordinates on Plate LIII, the character or status of the well, the name of the limestone bed nearest to the surface at the well, and the elevation of the well mouth. The logs of seven of these wells are given in Plate LIV, and the locations of the wells whose logs are given are shown in figure 52 .

Wells in Lacasa area, north-central Texas.

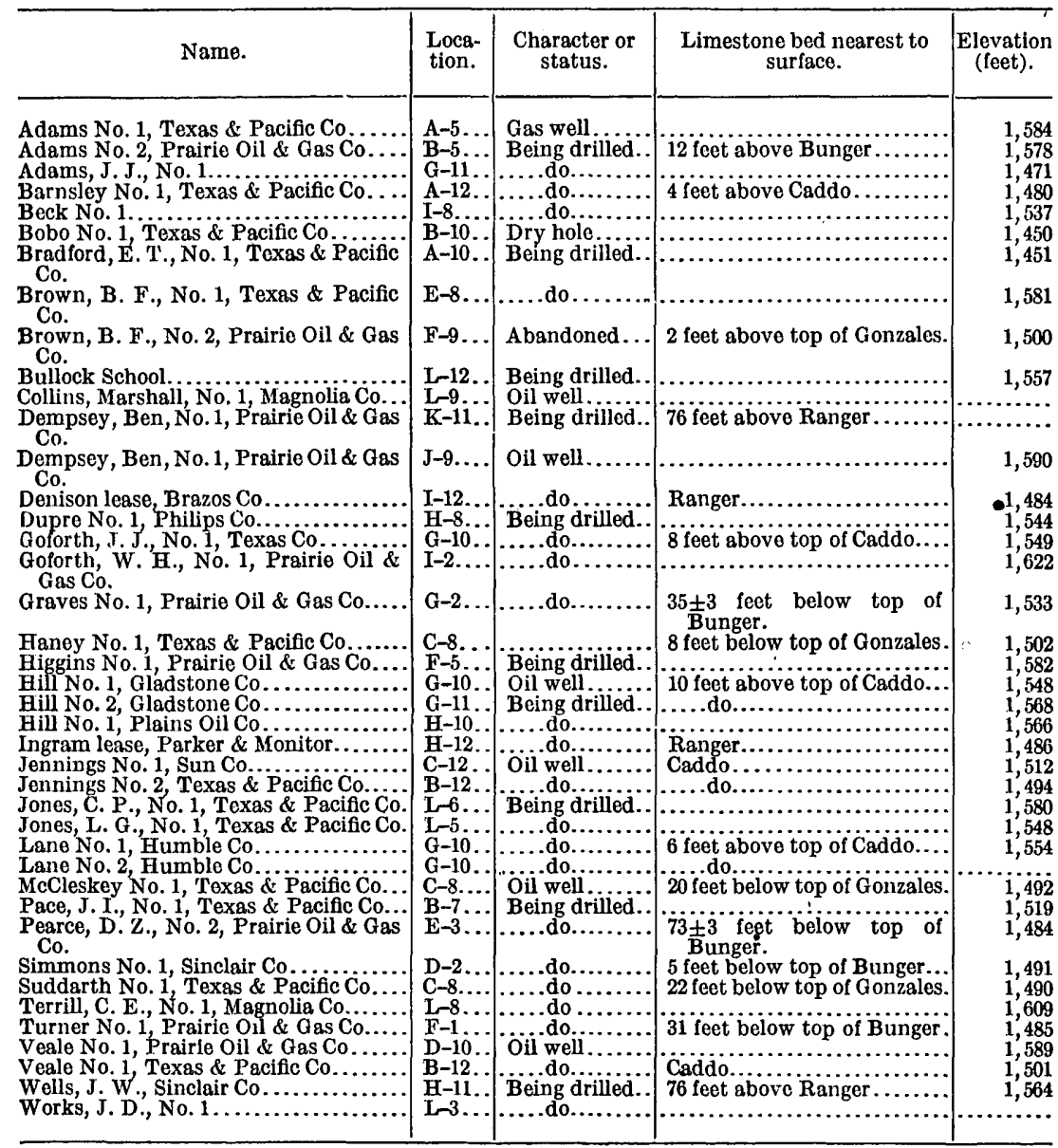


314 CONTRIBUTIONS TO ECONOMIC GEOLOGY, 1921, PART II.

Other wells near this area that were used in determining the structure are referred to the nearest coordinates on Plate LIII in the following table:

Wells near Lacasa area used in determining structure.

\begin{tabular}{|c|c|c|c|}
\hline Name. & $\begin{array}{l}\text { Loca- } \\
\text { tion. }\end{array}$ & Character or status. & $\begin{array}{c}\text { Elevation } \\
\text { (feet). }\end{array}$ \\
\hline 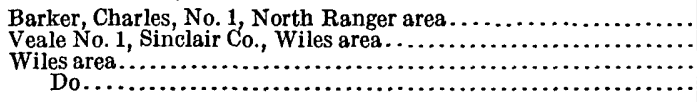 & $\begin{array}{l}L-5 \ldots \\
\mathrm{C}-12 \ldots \\
\mathrm{I}-12 \ldots\end{array}$ & $\begin{array}{l}\text { Being drilled...... } \\
\text { Oil well. } \\
\text { Being drilled......... } \\
\ldots \ldots . \text { do } \ldots \ldots \ldots \ldots\end{array}$ & $\begin{array}{l}1,545 \\
1,501 \\
1,598 \\
1,494\end{array}$ \\
\hline
\end{tabular}

Note.-In Plate LIV the location of well No. 2 (Adams No. 1, Texas \& Pacific Co.) should be given as 3 miles west of Lacasa, and that of well No. 3 (Haney No. 1) should be given as Stephens County, Tex., without more specific designation. 
U. S. GEOLOGICAL SURVEY

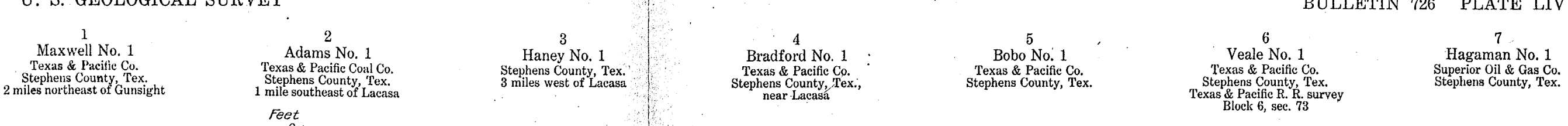

BULLETIN 726 PLATE LIV

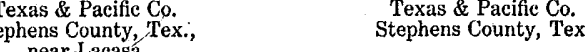

Fete

Finger limestone $10^{\prime}$ Home Creet
Blue $5^{\prime}$
Blue $100^{\circ}$ Blue 130' $130^{\circ} \quad 500$ Fine $80^{\circ}$ Black 15

Firic $30^{\circ}$

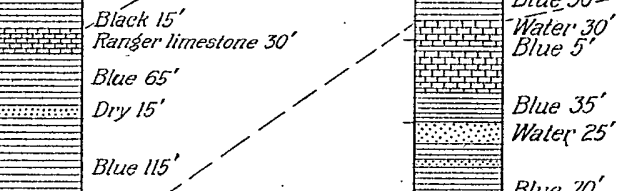

500

Blue $65^{\circ}$
Dry $15^{\circ}$

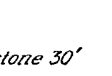

Water $20^{\circ}$

Blue $20^{\circ}$

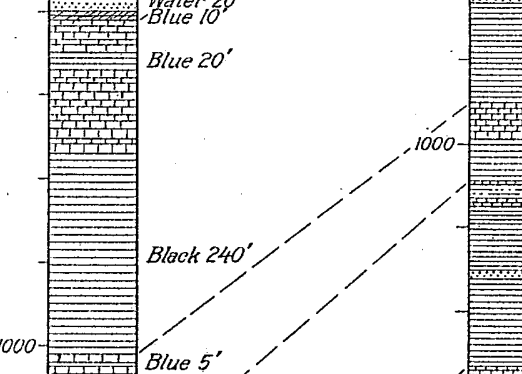

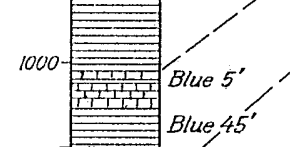

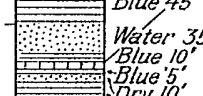

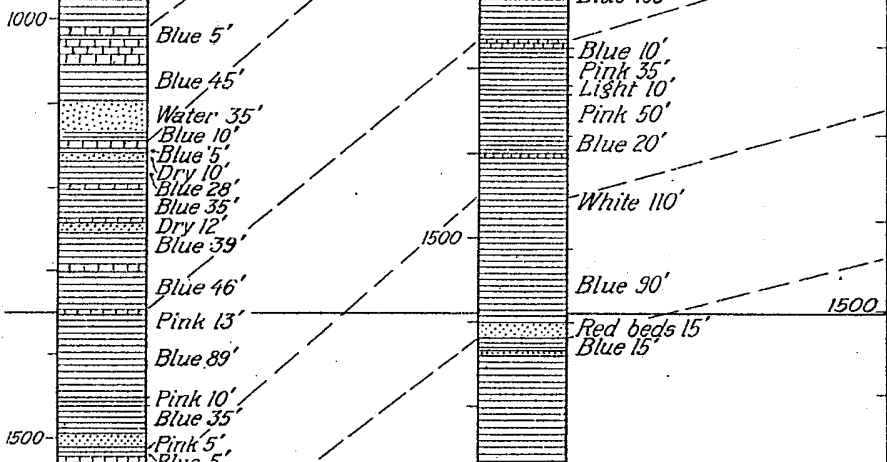

知

Pink, $117^{\prime}$

Pink $145^{\circ}$

.

Blue $150^{\circ}$

2000 Blue.72'

Blue.72

Blue

Water $200^{\circ}$

water $25^{\circ}$

$$
-
$$
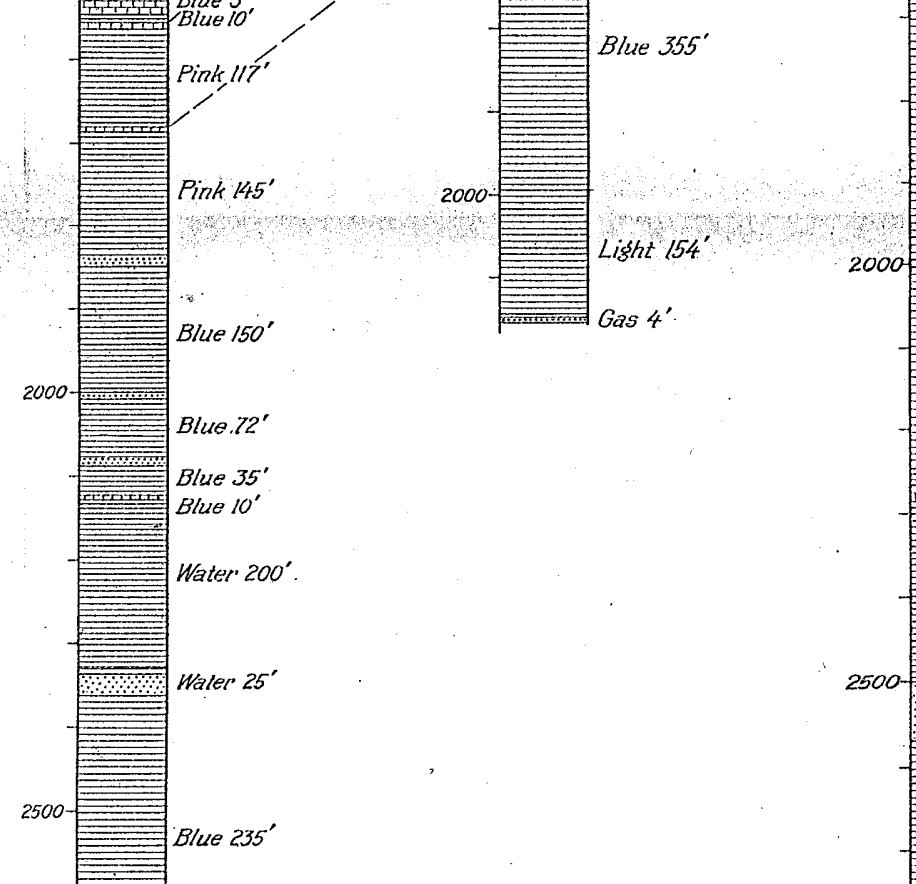

Blue $120^{\circ}$

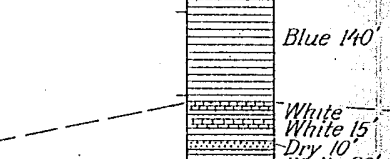

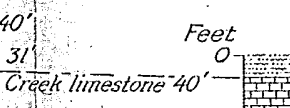

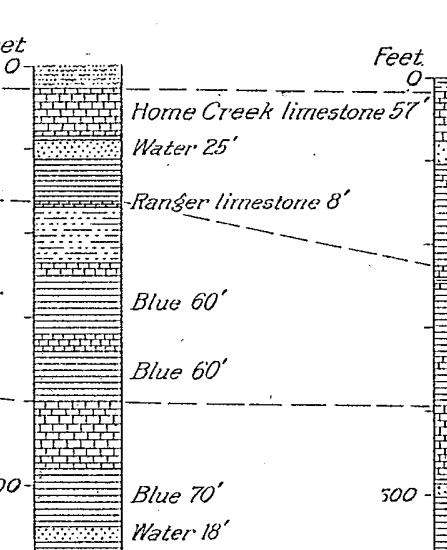

Feet<smiles></smiles>

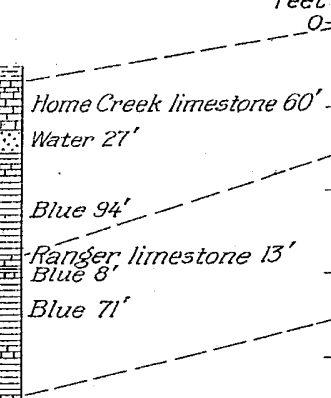

${ }_{0}^{a}=$

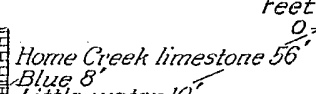

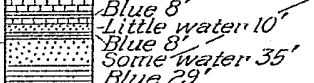

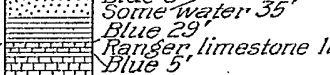

策

Ranger limestone $80^{\prime}$

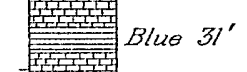

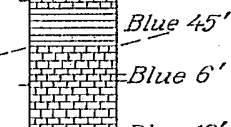
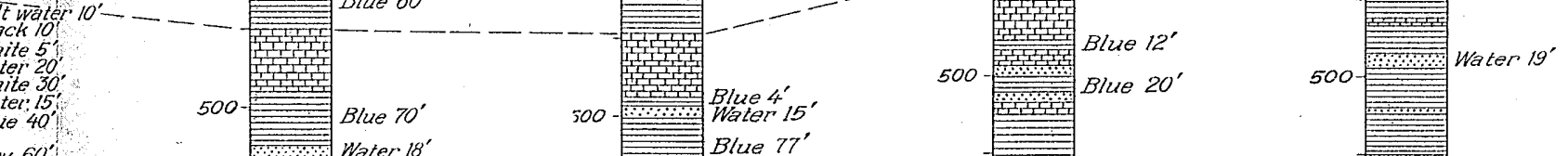

$20^{\prime}$
$30^{\prime}$
$40^{\prime}$
60

$15^{\circ}--$
$20^{\prime}$
water $20^{\prime}$
$50^{\prime}$

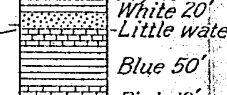

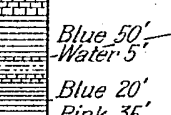

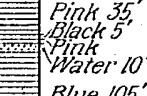

Blue 65

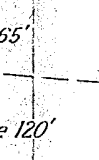

$120^{\prime}$

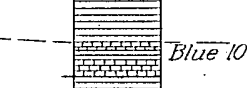

132'
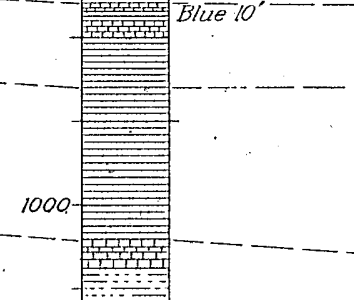

White 55

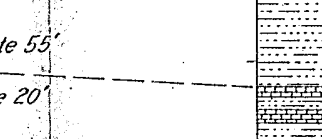

He 155'

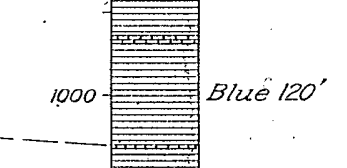

White $10^{\circ}$

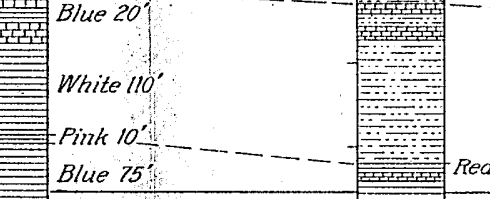

Blue 25
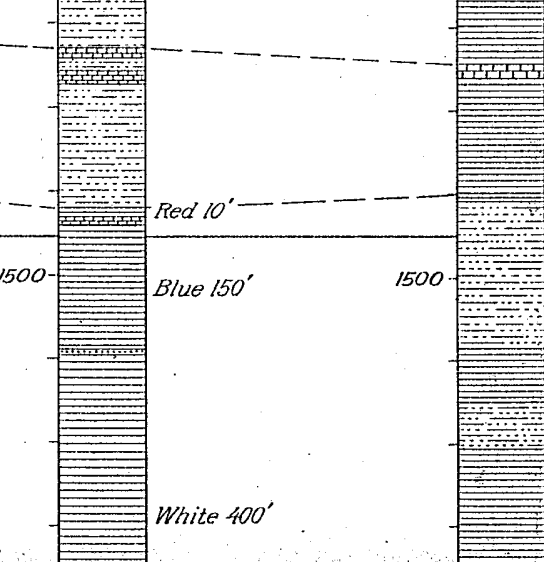

Blue 183'

Blue 1

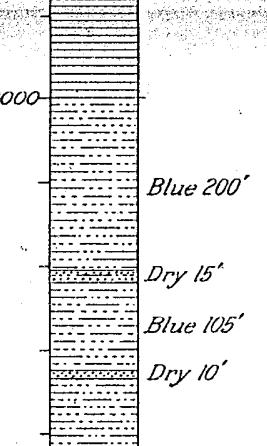

…

$$
-
$$
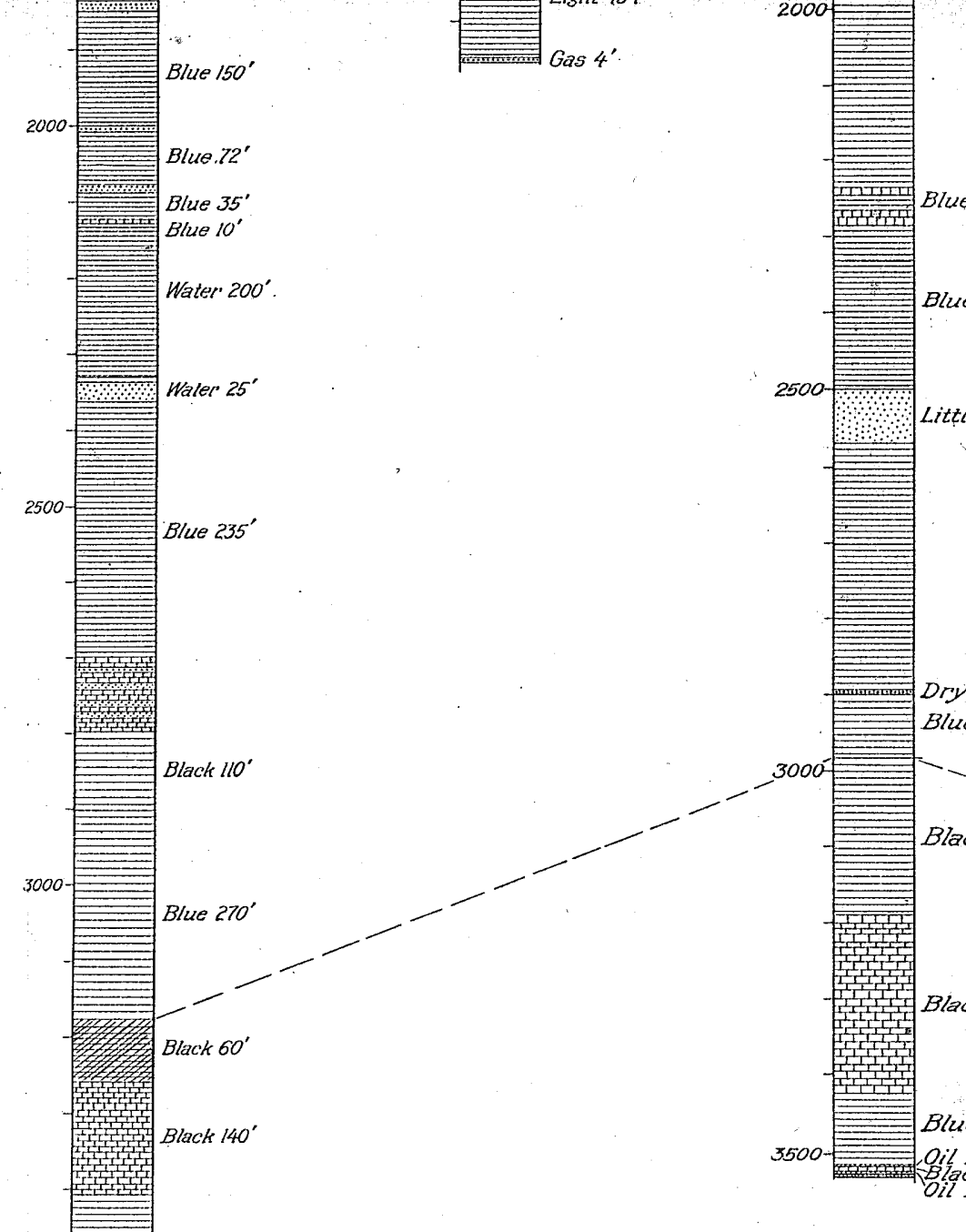

Black 140

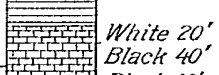

1r.

(1)

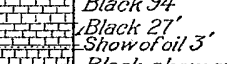

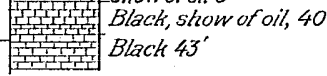

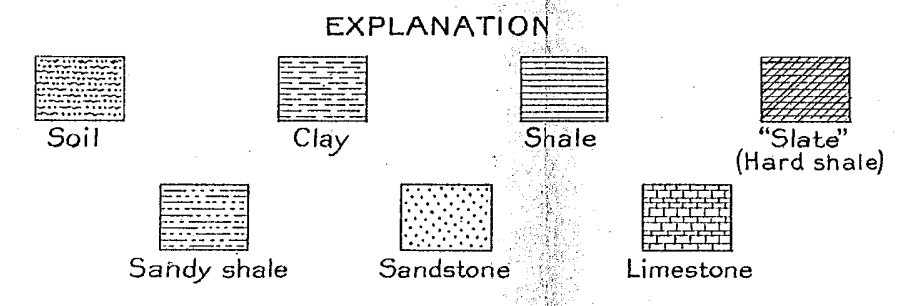

EXPLANATION
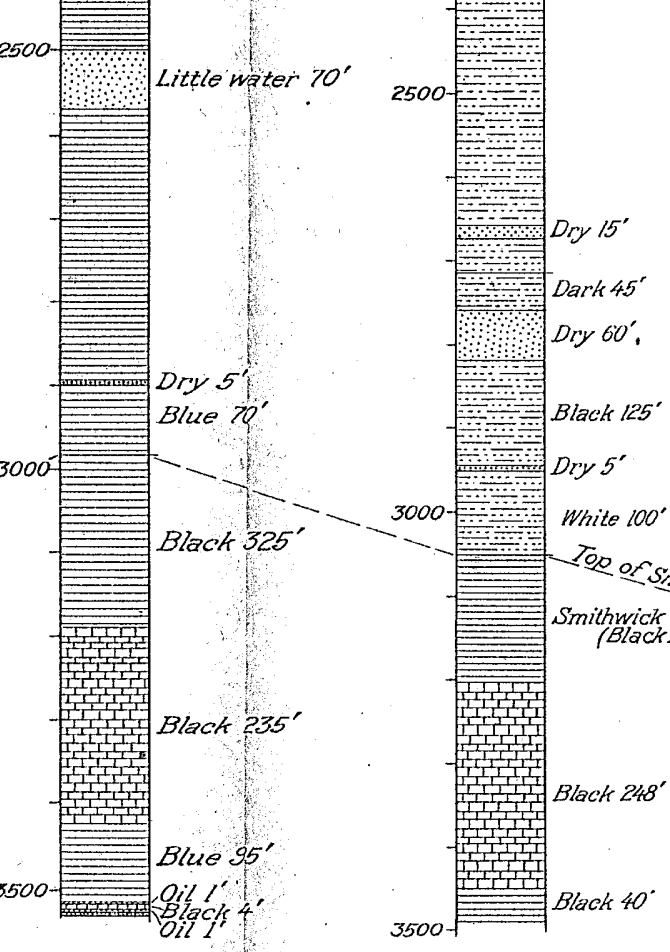

ry $15^{\prime}$

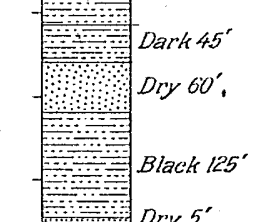

Dlack $125^{\circ}$
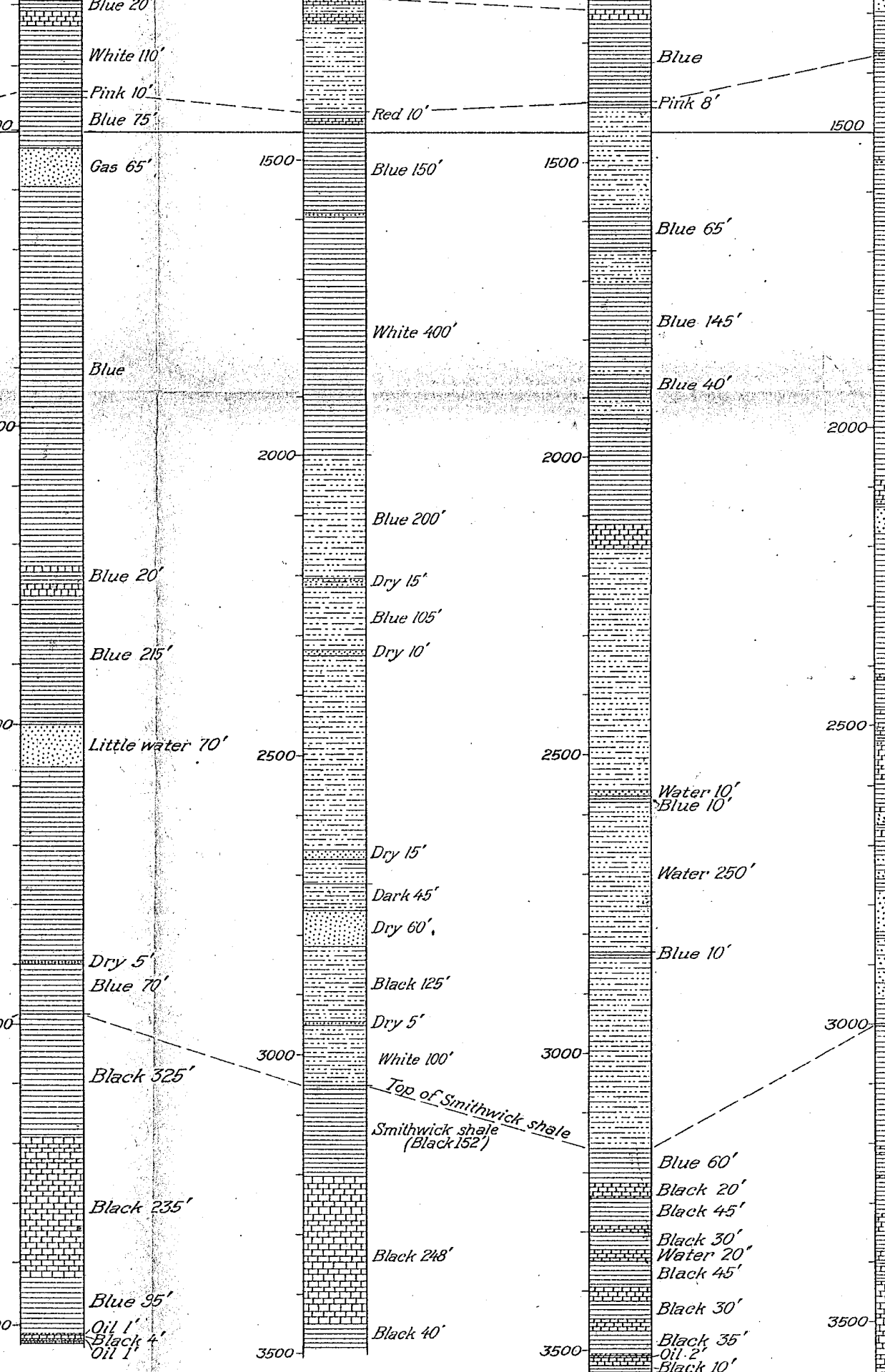

1000
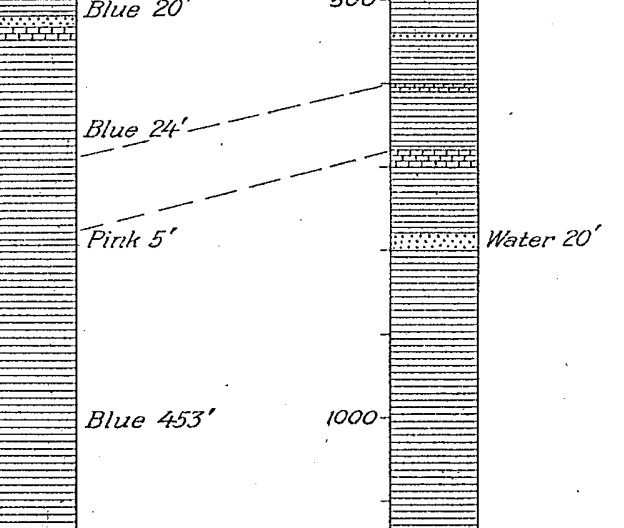

$453^{\circ} \quad 1000$

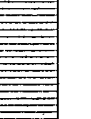




\section{INDEX.}

A.

Abo sandstone, distribution of, in New Mexico

Abo siding, N. Mex., formations penetrated at._-_- 219-220

Acknowledgments for aid 3,42,

$89,110,278$

Alamogordo, N. Mex., materials penetrated near-_._-- 227-228

Alamosa Creek, N. Mex., map showing structure in valley of

Animas Mountains, N. Mex., features of

Antelope Spring, Ariz., anticline near

Armijo, N. Mex., material penetrated at

Arroyo Chupadero, N. Mex., features of basin of

Atarque, N. Mex., Navajo and Dakota sandstones at, plate showing -......

uplift at, plate showing

\section{B.}

Badlands in the Fort Berthold Indian Reservation, N. Dak., distribution of - 111-112 plates showing

Bassler, Harvey, and Reeside, John B., fr., Oil prospects in Washington County, Utah - 87-107

Bauer, Clyde Max, work of _..... 110 and Herald, Frank A., Lignite in the western part of the Fort Berthold Indian Reservation south of Missouri River, N. Dak

Beck grant, N. Mex., record of boring on _...-

Becker, N. Mex., materials penetrated at._........-

Belt well, near Dayton, N. Mex., gas and oll from

Blg Hatchet Mountains, N. Mex., features of ..........

Black Rock Canyon, Arlz., section in showings of oil in
Black Rock Mountains, Ariz., domes near-_.....-...-

Bliss . sandstone, San Andres Mountains, N. Mex., plate showing -

Bloomington dome, Utah, description of _._._._. 102-103

favorable locallty for drilling on_._. 107

Bluewater Canyon, N. Mex., plate showing -..........

Bluewater Falls, N. Mex., Dakota sandstone at, plate showing--_-_.-.--

Bluewater station, N. Mex., record of boring at_......

Bodega, N. Mex., materials penetrated at_...........

Bonine, C. A., work of _._._._.Boulders, glacial, in N. Dak., plates showing-_._. 7,141

"Breaks," occurrence of _._._.- 111 of the Little Missouri, near Hans Creek, N. Dak., plate showing

Brown oll well, near Dayton, N. Mex., yield of _._._.-. 211

Buchanan, N. Mex., formations penetrated south of --

Bunn, Frank, work of _._.

Buttes in North Dakota, plates showing

in Squaw Creek valley, N. Dak., plate showing-on Hans Creek, N. Dak., plate showing

C.

Caddo oil sand, features of ,in the Cement oil field, Okla

Caddo Petroleum Co., analysis of oil produced by -...-.--

Campbell, M. R., acknowledgment to

Cannonball marine member of the Lance formation, in North Dakota, features of _......... 5-6, 7, 8-10 showing 7

Carrizalillo Hllls, N. Mex., features of _- 273

Carrizozo, N. Mex., materials penetrated at_..._..._. 228-229 
Carlsbad, N. Mex., formations penetrated south of $-1 \quad 216$ record of boring near

Carter Oil Co., records of borings made by_..__._._-_ 261, 262

Carthage, N. Mex., structure north of -_._-_._-_ 234-237

Cedar Grove Mountains, N. Mex., features of ......-

Cement anticline, Okla., description of - $63-65$

Cement area, Okla., topography of -- 43-44 Cement dome, Okla., description of Cement oil field, Okla., development of -

development of, future direction of _...

drainage of 44

extent of .....

geography of

geology of _..........

key rocks in _...

logs of wells in, plate showing $\quad 72$

new oil sands in, probability of finding -...

oil from, grade of

possibility of ofl beyond the limits of ........-

production from

reasons for investigation

soil and climate of

statistics of wells in _....... 77-79

structural map of ........ In pocket. topography of, partly determined by structure

towns and roads in _._._._._. 44-45

unexposed rocks in _........ 56-57

Cerrillos Basin, N. Mex., Dakota sandstone in, plate showing _..._._._-_ 220

features of _.

Cerrillos del Coyote, N. Mex., structure south of _._._. 234-237

Chama Basin, N. Mex., stratigraphy of

structure of

Chapelle, N. Mex., record of boring at_.................

Chaves County, N. Mex., borings in progress in

stratigraphy and structure of -

Chupadera formation, nature of, in New Mexico_._._._. 181-182

Chupadera Mesa, N. Mex., plate showing

stratigraphy and structure of - 221-223

Cibola Cone syncline and fault, $N$. Mex., features of_._._. 237

Clapp, F. G., cited

Coal, analyses of -._-_-_-_-_-_ 17-20

heating value of

Cobb syncline, Okla., description of- 66-68 Color, changes in, produced by ascending solutions.
Columbus, N. Mex., material penetrated near.......-

Comanche limestones and sandstones, distribution of, in New Mexico

Concretions, log-form, in the Fort Union formation, plate showing

Page.

272

185

140

270

Cooks Range, N. Mex., features of Coyote Butte, N. Mex., plate show-

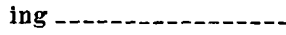

Crown Butte, near New Salem, N. Dak., plate showing---

Crown Point, N. Mex., log of boring northwest of _._._. 251-252

Cutter, N. Mex., materials penetrated south of -.....-

Cyril gypsum, member of the Greer formation, effects of erosion on, plates showing _._. 48,49

features of ....... $48-50$

Cyril syncline, Okla., description of _- 65-66

D.

Dakota Products Co., lignite mining by

mine of, plate showing

Dakota sandstone, at Atarque, $\mathrm{N}$. Mex., plate showing --

at Bluewater Falls, N. Mex., plate showing

196

196

In Cerrillos Basin, N. Mex., plate showing

occurrence of, in Union and Mora counties, N. Mex.

Darton, N. H., Geologic structure of parts of New Mexico 173-275

Daw-Bell Development Co., log of well of .............

Dayton, N. Mex., oil wells near....-

Dayton Petroleum Co., record of boring by

Dean, E. W., analysis by

214

Defiance siding, N. Mex., record of boring at ............

Deming, N. Mex., materials penetrated near.......

Dips mistaken for structural dips_._ $52-53$

Dog Canyon station, N. Mex., materials penetrated near.- 227

Dumble, E. T., and Cummins, W. F., cited

279

E.

Eagle's Nest butte, N. Dak., situation of ...................

Eaton grant, N. Mex., record of boring on -._.

Fddy County, N. Mex., borings in progress in stratigraphy and structure of $210-216$ 
El Paso \& Southwestern Railroad Co., wells bored by, in New Mexico_ 227-229, 232-234

Empire Gas \& Fuel Co., log of well of, in Jefferson County, Okla___._._._._._. 288-289

Engle, N. Mex., materials penetrated at and near._._._. 232

Estancia Valley, N. Mex., geology of _.

Esterito dome, N. Mex., description of _-____._. 195-196

record of boring in 198-199

F.

Tairview, N. Mex., geologic features south of -

Farmington, N. Mex., record of deep well near._._.

Farmington Oil \& Gas Co., record of well bored by _-_-_- 249-250

Fath, A. E., work of

Flora Vista, N. Mex., formations penetrated near.-.--- 251

Florida Mountains, N. Mex., features of _._._- 270

Florida Plains, N. Mex., features of _..._._._._._. 270,272

Fort Berthold Indian Reservation, N. Dak., drainage of _ 112-113

field work in _...-- 109-110, 110-111

lignite in, beds of _._....... 128-129

beds of, plates showing-112, 142 sections of, plates

showing- $132,144,154,172$

distribution of - 126-127, 129-172

quantity of

utilization of _........ 127-128

value of

location of _..... 109

map of northern part of _._. In pocket map of southern part of _-_._In pocket map of southwestern part of.In pocket physiography of 111-113 rolling upland in, plate showing

153

settlement and industry in

stratigraphic sections in, plate showing-_..... 128

stratigraphy of

structure of _._._._._._. 117-119

Fort Union formation, bare buttes of, on Hans Creek, N. Dak., plate showing--

blufts of, in North Dakota, plate showing -...-_ 153

features of, in North Dakota $-5,6$,

fossil $\log$ and stump in, plates $8,10-11$ showing - 152

log concretions in, plate showing

152

nature of, in the Fort Berthold Indian Reservation, N.

Dak__._._._. 114-117

origin of

118-119
Fortuna Oll Co., analysis of oil produced by

Fage.

$\log$ of well of

74

ortuna oil sand, features of, in the Cement oll field, Okla_

Fossils, occurrence of, in New Mexico_-...-- 180, 181, 182

occurrence of, in Fort Berthold Indian, Reservation, $\mathrm{N}$. Dak .......... 110

Fruitland, N. Mex., record of deep well north of

\section{G.}

Gallup, N. Mex., record of city arteslan well at record of well southwest of.... $\quad 262$ Gallup-Zuni Basin, N. Mex., records of borings in_._._- 260-262

stratigraphy of - 259

structure of _._._._. 257-258, 259-260

Gardner, J. R., acknowledgment to -- 190

Gibson, N. Mex., formations penetrated at____._._- 262

Girty, G. H., fossils determined by - 180, 181

Glaciation, effects of, in the Fort Berthold Indian Reservation, N. Dak_....-

Gladstone Oil Co., analysis of oil produced by _....... 75

$\log$ of well of

Glorieta Mesa, near La Cuesta, N. Mex., sandstone of, plate showing 188

structure of

Goldman, M. I., acknowledgement to_ $\quad 42$

Goodridge, Utah, oil wells at__.._ 246-247

Goodsight Mountains, N. Mex., features of

Gordon, C. H., cited_____-_ 268, 285

Grafton, Utah, locality favorable for drilling near_...... 106-107

Greer formation. See Cyril gypsum member.

Guadalupe County, N. Mex., record of boring in_._._._-_ 204-205

Guam, N. Mex., record of boring at_- 257

Gypsy Oil Co., record of hole bored by _....... 198-199

H.

Hager, Lee, cited_._-_._-_._- 291-292

Hancock, Eugene T., The New Salem lignite fleld, Morton County, N. Dak__._. 1-39

Hans Creek, N. Dak., sage-brush flat of, plate showing- 153

Harrisburg dome, Utah, description of _._._._. 99-101, 107 section of 92

Heald, K. C., acknowledgment to _.. 42 cited.- 56

Heart River, N. Dak., valley of, plate showing 
Herald, Frank A., work of --_---Herald, Frank A., Bauer, Clyde Max., and, Lignite in the western part of the Fort Berthold Indian Reservation south of Missouri River, N. Dak__._. 109-172

Hurricane fault scarp, Utah, section of

\section{I.}

Inscription Rock, N. Mex., plate showing.-..-..-

J.

Jefferson County, Okla., southern part, earlfer geologic work in _._._._._. 277-278 southern part, field work in_.- 278 geography of special area in Grogan anticline in prospecting in

"Red Beds" In_._._-_- 278-279

Red Creek anticline in _... 209, 301,302 sand dunes in

Seay anticline in --- 299, 301-302 stratigraphy of _._-___ 278-279 structural features in _._ 297-300 map showing _._._._. 284

Tertiary residual deposits in _........... 284-285

Trinity sand in

unexposed rocks in ....- 285-297

wells in, logs of _...--_ 286-297

Wichita formation in

Jones, B. B., well, Jefferson County, Okla., $\log$ of

Jornada del Muerto, N. Mex., geologic eatures of _- 229-230 geologic map of structure of Joyita Hills, N. Mex., geologic features of _._._._._. 239-240

\section{K.}

Keeche dome, Okla., description of - 63-65 Keeche Hills, Okla., origin and form of

Keeche Oil \& Gas Co., $\log$ of well of $82-83$ Kenzin siding, N. Mex., record of deep well at

234

"Kingman dome," Utah, description of - 103

Kiowa area, Okla., structure of ___ 68-69 structure of, map showing_-_In pocket. topography of

Klondike Hills, N. Mex., features of $\quad 273$ Knowlton, F. H., acknowledgment to 110 fossils determined by_..- 6, 7, 11, 116
I.

Lacasa area, Tex Adams anticline

in

Atkins anticline in _._._._. 311-312

Bunger limestone in ........ 308

gas well in _._._._._._. 310,312

geography and mapping of _-_ 303-304

Gonzales dome in ........ 311

Gonzales limestone in_..._-_ 307-308

Home Creek limestone in _._. 306-307

Hagaman terrace in _._._... 309

oil wells in__._._._._. 310,313

Ranger limestone in_........ 306

stratigraphy of _._._._-_._- 304-308

structure of - 308-312

map showing -........ 308

Veale anticline in

wells and $\mathrm{b}$ or $\mathrm{ing} \mathrm{s}$ in and

near._._._._. 313-314

plate showing records of - 314

Laguna, N. Mex., materials penetrated near._._._- 265

La Jara Peak, N. Mex., boring east of - 266

Lake Valley, N. Mex., geologic features north of _.___- 268-269

Lance formation, features of, in North Dakota__._._ 5, 6, 7,9

Landslides on Missouri River, $\mathbf{N}$. Dak., features of 162 163,166

La Plata group, nature and distribution of, in New Mexico

184

Lee, W. T., cited_._. 191

Lemitar Mountains, N. Mex., geologic features of

Lenark, N. Mex., record of deep well at_._. 233

Lignite, analyses of

burning of beds of _._._._._. 117

heating power of .......... 123-124

importance of, in North Dakota

in Fort Berthold Indian Reservation, N. Dak., nature and distribution of - 119-172

in New Salem field, N. Dak., nature and occurrence of

sections showing features of _... 14

Lincoln, N. Mex., anticline west of_ 209-210

Lincoln County, N. Mex., basin in _- 209

Little Hatchet Mountains, N. Mex., features of

Little Missouri River, "breaks" of, near Hans Creek, N. Dak., plate showing --

features of, in Fort Berthold Indian Reservation, N. Dak_.

intrenchment of._._._. 111 
Log, fossil, standing in the Fort Union formation, $\mathrm{N}$. Dak., plate showing--

Lordsburg, N. Mex., materials penetrated near

Lucy, N. Mex., formations penetrated at

M.

McGee boring, Quay County, N. Mex., $\log$ of

McKinley Oil \& Drilling Co., log of well of

Magdalena group, base of, plate showing

nature and distribution of, in N. Mex _______ 179-180

upturned beds of, plate showing

Malpais siding, N. Mex., materials penetrated at

236 at

Mancos shale, features of, in New Mexico-...-

Manzano group, nature and distribution of, in New Mexico -

Manzano Mountains, N. Mex., geologic map of _._._. 218

structure of

Marion Oil \& Gas Co., log of well of, in Jefferson County, Okla_________ 290-291

Matson, G. C., acknowledgment to _- 196 ,

Mesa del Yeso, N. Mex., plate showing

198

Mesaverde group, subdivisions and distribution of, in New Mexico__. 185-186

Missouri River, features of, in Fort Berthold Indian Reservation, N. Dak

from upper margin of the badlands, in North Dakota, plate showing -...---

Moccasin Creek, N. Dak., valley of, plate showing -..-_--

Mohave County, Ariz., possibilities of oil in

Moore, Raymond C., work of _..._. 3

Morrison formation, nature and distribution of, in New Mexico__-_._._-_- 184-185

Mount Riley siding, N. Mex., materials penetrated at.-

N.

Nacimiento uplift, N. Mex., stratigraphy of -

structure of._._...... 241, 242

Navajo Church, N. Mex., sandstones at, plate showing....

Navajo sandstone, at Atarque, N. Mex., plate showing--

in New Mexico, nature and distribution of
Page.

Negra, N. Mex., formations penetrated at._.

Page.

New Mexico, conditions favorable and unfavorable to oil in central eastern, records of borings in stratigraphy of structure of Colfax County, dome in _._._ 182-190 east-central platenu region, records of borings in 203-205 stratigraphy of _._._. 201-202 structure of _._....... 202

Luna County, ridges in northwest corner of _..._... 274

map of _... 174 northeastern, dome in _..... 189-190 formations in records of borings in _... 192-194 stratigraphy of._-_._- 190-192 structure of -..._. 192 northwestern, formations in I $^{177-178}$ older Paleozoic rocks in, complete exposure of._-_ 179 sedimentary rocks in, general succession of - - - 175-179 southern, formations in _._. 178-179 southwestern, geologic features of -

Union County, dome in _._._- 189-190 west-central volcanic area, geologic features of _-_-- 267

New Salem lignite field, N. Dak., access to

early explorations near......- 3-4

field work on

geography of _... 4-5

geology of

map showing-_._._-_._- 38

lignite in, chemical properties of _._._. 15-17, 20, 21

exposures of

heating value of ......... 21-23

mining of

origin and distribution of - 12-14

physical properties of --_-- 14-15

location of 1,2 towns in

upland in vicinity of, plate showing - 6

Noria, N. Mex., materials penetrated at_-__- 232-233

North Chaves siding, N. Mex., record of well at____._- 255-257

North Garcia siding, N. Mex., materials penetrated at - 264-265

\section{0.}

Office of Indian Affairs, cooperation by-

Oil. See Petroleum.

Oklahoma, geologic map of, showing oil and gas fields_._-- 42

index map of 
Orchard Park, N. Mex., formations penetrated near

Orogrande, N. Mex., materials penetrated at

Oscura anticline, N. Mex., structural features of

Oscuro, N. Mex., materials penetrated at...........

P.

Parks, E. M., work of

Pastura, N. Mex., rocks penetrated by well at_.......--

Pecos River valley in Chaves and Eddy counties, N. Mex., oil in

records of borings in ....... 212-216

stratigraphy of _._._._._._- 210-211

structure of

Pedernal Siding, N. Mex., formations penetrated at.--

Peloncillo Mountains, N. Mex., features of -

Petroleum, accumulation of, relation of structure to _._._. 61-62

formations likely or unlikely to contain, in New Mexico

occurrence of, in the Pecos River valley, N. Mex _ 211-212

Picacho, N. Mex., dome near._._- 209

formations penetrated by boring near.

Pierce, O. H., work of

Pilot Knob, N. Mex., plate showing-Pintada Canyon, N. Mex., dome in -Plains of San Agustin, N. Mex., geologic features of

wells bored in

Platt well, near Dayton, N. Mex., gas from

Plummer, Frederick B., cited......-

Prairie Spring anticline, N. Mex., structural features of --

Producers Oil Co., $\log$ of well of, near Petrolia, Tex _ 292-294

Prosperity oil sand, features of, in the Cement oil field, Okla

Pueblo Bonito School, McKinley County, N. Mex., materials penetrated near.-

Purgatoire River, south fork of, in N. Mex., geologic section on

Pyramid Mountains, N. Mex., features of

Pyramid Rock, N. Mex., plate show. ing

Q.

Quaternary deposits, nature and distribution of, in New Mexico
211

205

275

Page.
Quemado, N. Mex., boring northeast Pag of _.

\section{R.}

Raton coal field, N. Mex., formations present in

Ifkelihood of oil and gas in _-_ 192

"Red Beds," distance of oil sands below, in Texas and Oklahoma_._._-__ 295-296

improbability of oil in _._._._._ 187-188

orfgin of _._._. 58

Permian, nature and distribution of, in New Mexico _._.

Triassic, nature of, in New Mexico__._-_. 182-183

Reeside, John B., jr., acknowledgments to_.._._._. 250, 251

Bassler, Harvey, and, Oil prospects in Washington County, Utah_.._-_ 87-107

Reeves, Frank, Geology of the Cement oil field, Caddo County, Okla__._._. 41-85

Rio Grande valley, in central New Mexico, géologic features of 220-221

in nortbern New Mexico, formations in 217

in, southern New Mexico, materials penetrated in

Rio Puerco station, N. Mex., materials penetrated at.

Rio Salado valley, N. Mex., map. showing structure of

Robinson, Heath M., Geologic structure and oil and gas prospects of a part of Jefterson $C^{\prime}$ o u n $t \mathrm{y}$, Okla___________ 277-302

Rocky Mountains, prolongation of in New Mexico _..... 202

structure of, in New Mexico- 200-201

Ross, Clarence S., The Lacasa area, Ranger district, northcentral Texas__._._ 303-314

Roswell, N. Mex., records of borings near_..._.

Roundy, P. V., acknowledgment to $\quad 42$ cited.... 293

Ryan, Jefferson County, Okla., anticline east of $300,301,302$

Ryan City Oil Co., $\log$ of well of, in Jefferson County, Okla

\section{S.}

Sacramento Cuesta, N. Mex., formathons penetrated by boring in _... 210

stratigraphy of 207-208 structure of 209-210 
Sacramento Mountains, N. Mex. west front of, plate showing -

Sago-brush flat of Hans Creek, N. Dak., plate showing--

St. George, Utah, anticlines near- 103-104 composite section for region near 92-93

San Agustin plains, N. Mex., geologic features of -.... wells bored in

San Andres Mountnins, N. Mex., geologic features of.-

Sandia Mountains, N. Mex., geologic map of - 218

structure of

west front of, plate showing--- 218

San Ignacio, N. Mex., dome near, plate showing

San Juan Basin, N. Mex., oil and gas in _..... 246-247

records of borings in

structure of - - - - 245-246, 247-248

San Juan Basin O1l \& Gas Co., records of deep wells bored by

San Luis Range, N. Mex., features of

Seay, Oscar, well No. 1, Jefferson County, Okla., $\log$ of. 287-

Seven Lakes, N. Mex., formations penetrated near...-..-

Shea, Edward F', work of

Sierra de los Pinos, N. Mex., geologic map of

structure of

Sierra Lucero, N. Mex., sections across, plate showing

Sierrita Mesa, N. Mex., plate showing

Sims, N. Dak., syncline at.....

Socorro County, N. Mex., geologic maps of parts of -..- 234, 262

eastern part, structure of --- 234-241 north-central part, stratigraphy of structure of -

Socorro Mountains, N. Mex., geologic features of --- 240-24.1

Southern Pacific Co., records of wells bored by

Southspring Ranch \& Cattle Co., record of boring by -- 214-215

Springs in Fort Berthold Indian Reservation, N. Dak., features of

Squaw Creek, N. Dak., vlew on .... 161 Staked Plains region in N. Mex., boring in

formations in

Stanton, T. W., acknowledgment to- $\mathbf{1 1 0}$ fossils determined by

State wells, Torrance County, N. Mex., records of
Steiger, George, analyses by

Stinchecum, C. V., acknowledgment

to _..._... 42

Strauss, N. Mex., materials penetrated at.

l'age.

74

232

Stump, fossil, in the Fort Union formation, plate showing-

Suwanee, N. Mex., materials penetrated near._...

Swanker, Sidney, work of

T.

Tannehill well, N. Mex., record of.-Taylor coal basin, N. Mex., geologic features of

Tertiary deposits, nature and distribution of in New Mexico__.

Texas, north-central, Pennsylvanian formations in ...... 285

Tijeras, N. Mex., anticline north of- 218 Tinnie, N. Mex., dome near._.... 209

Todilto formation, nature and distribution of in New Mexico-_.-.

Tohachi, N. Mex., record of well southeast of

Toltec Co., records of borings made by _.._-_._ 203-204, 21.2-213

Tres Hermanas Mountains, N. Mex., features of

Tularosa Basin, N. Mex., geologic map of - 224

materials penetrated in._-_-- 227-229 stratigraphy of structure of

\section{U.}

United Oil Co., record of boring of, in Union County, $\mathrm{N}$. Mex_._. 193-194

\section{V.}

Valencia County, N. Mex., gcologic map of part of east-central part, records of borings in stratigraphy of _._._._. 263,264 structure of

Valle del Ojo de la Parida, N. Mex., features of

Valle Grande area, N. Mex., features of -D.... 245

Victorio Mountains, N. Mex., features of - 273

Virgin anticline, Utah, description of - 99-103

Virgln City, Utah, localities favorable for drilling near $\quad 106$

oil wells near....... 93-95, 96 Virgin River, section in narrows of, Ariz_____. 92-93 
W.

Washington County, Utah, difficulties of drilling in _.- 106

geology of

gas in _..... 95

ground water in

industry and settlements in..- 87-88

location and geography of _..- 87

oil in, commercial production

of -

source of _._._._ 95, 96-97, 98

oil prospects in

prospecting for oil in

structure in

Washington dome, Utah, description of _._._._._- 101-102

favorable locality for drilling on

Water, force compelling upward movement of .........-

Wells, R. C., acknowledgment to....

White, Bruce, work of

White, David, acknowledgment to -fossils determined by

Whitehorse sandstone member of the Woodward formation, cross-bedding in, origin of
Whitehorse, cross-bedding in, plate showing -........

Fagc.

erosion features of, plates showing _......._._. 48,49

sandstone member of the Woodward formation, features of._._._-_._- 51-56

types of ........

Wichita Mountains, development of _ $\quad \mathbf{4 5}$

Winchester, Dean E., cited__-_- 265, 268

Williams, Delbert, work of _._... 3

Wingate sandstone, at Rito, N. Mex., plate showing-- 188 nature and distribution of, in New Mexico__._._._.' 184

Woodruff, E. G., acknowledgment to

Woodward formation. See Whitehorse sandstone mem. ber.

$\mathbf{Z}$.

Zuni Mountains, N. Mex., records of borings in_._-_._- 254-257

stratigraphy of -_-_-_-_-_- 254

structure of _... 253

Zuni uplift, N. Mex., plates show-

ing 